Portland State University

PDXScholar

\title{
'Do not mistrust my age or power': Daughterly Agency in Three Elizabethan Family Drama Plays
}

Andreas P. Bassett

Portland State University

Follow this and additional works at: https://pdxscholar.library.pdx.edu/honorstheses

Let us know how access to this document benefits you.

Recommended Citation

Bassett, Andreas P., "'Do not mistrust my age or power': Daughterly Agency in Three Elizabethan Family Drama Plays" (2018). University Honors Theses. Paper 578.

https://doi.org/10.15760/honors.586

This Thesis is brought to you for free and open access. It has been accepted for inclusion in University Honors Theses by an authorized administrator of PDXScholar. Please contact us if we can make this document more accessible: pdxscholar@pdx.edu. 
'do not mistrust my age or power': Daughterly Agency in Three Elizabethan Family Drama Plays

by

Andreas Bassett

An undergraduate honors thesis submitted in partial fulfillment of the requirements for the degree of

Bachelor of Arts

in

University Honors

and

English

Thesis Adviser

Dr. Jonathan Walker

Portland State University 
In the latter half of the 1590 s and early 1600 s, the two prominent rival London playing companies, the Admiral's Men and the Lord Chamberlain's Men, engaged in a competitive backand-forth imitation game, putting on parallel plays that were in vogue. Three comparable plays with titles resembling each other were staged and featured similar plotlines but attempted to offer differing representations of middle-class families. Henry Porter's The Two Angry Women of Abingdon, William Shakespeare's The Merry Wives of Windsor, and the apocryphal The Merry Devil of Edmonton are models of family drama plays that were staged in the late-1590s and early-1600s during this tug-of-war period when London theatre rivals contested each other over audienceship. The Two Angry Women originated from the Admiral's Men while the Merry Wives and Merry Devil originated from the opposing Lord Chamberlain's, and later, King's Men. ${ }^{1}$

What plays remain from this lesser-known genre of family drama has received somewhat little scholarly attention when compared to other more famed genres such as the revenge tragedy. ${ }^{2}$ Regarding the business-minded rivalry and milieu from which the family drama plays emerged from, Andrew Gurr states, “between 1594 and $1600 \ldots$ only two companies [Admiral's and Lord Chamberlain's Men] were competing for the London playgoing crowds," "many of the plays on both sides . . imitated the rival repertory," and that "the interaction between the two companies, the oxymoronic impulse to display variety in similarity, was an intricate exercise"

\footnotetext{
${ }^{1}$ Evett states, "The Two Angry Women was printed in 1599, and has generally been thought to date from about 1598, shortly before the performance of the Second Part of the Two Angry Women in February, 1599. The title page of the Huntington first quarto has 'as it is played' rather than 'lately played' as the other copies have it; all copies indicate it was played by the Admiral's Company" (11). Both first quartos of Merry Wives and Merry Devil designate the Lord Chamberlain's/King's Men as the associated play company on the title pages. Merry Wives was first printed in 1602 but is generally thought to have been written around 1597, and though the Merry Devil was first printed in 1608, scholars believe it to have been written sometime between 1598 and 1604 (Abrams 29).

${ }^{2}$ Ashley H. Thorndike and F. G. Fleay's research place the height of the revival of revenge tragedies at the turn of the century: "Mr. Fleay has already shown proof that 'revenge for a father' plays were popular on the stage during these years [1599-1604] and that Marston, Chettle, Tourneur, and Jonson, as well as Shakespeare, were engaged in supplying the stage demand" (Thorndike 127). Revived revenge tragedies such as the Admiral's Men's The Spanish Tragedy (1602) and the Lord Chamberlain's Men's Hamlet Q1 (1602), as well as a handful of other non-revived plays that followed in suit with this trend (e. g. The Tragedy of Hoffman [1602], Antonio's Revenge [1602]), is further proof that points to an imitative theatrical practice and environment, one that fed into the appetites of London theatregoers and what generally came to be considered popular entertainment at the time.
} 
(“Intertextuality at Windsor" 189, 192, 193). Financer, manager, and employer of the Admiral's Men, Philip Henslowe, from whom we have the invaluable Henslowe's Diary, appears to have been keenly aware of the movements of his competitors and actively worked to respond to their movements: "Many of Henslowe's financial choices made in the period from 1599 to 1602 can be best explained as reactions to the actions of the Chamberlain's Men ... One could say more about the ways in which the two chief playing companies in the 1590 s saw each other as rivals . . . the two repertories must have been interrelated" ("Intertextuality in Henslowe: A Reply" 397). Gurr's notion of "one repertory feeding off the other's successes" (“Intertextuality at Windsor" 193), as well as the much more extensive historical context and intricacies of copying repertoires as a general Elizabethan theatrical practice arising from competition, sets the imitative framework in which Two Angry Women, Merry Wives, and Merry Devil were conceived, produced, and acted on stage. ${ }^{3}$

Similar to how the later city comedy plays of the early Jacobean period involved the portrayal of common inner-city (often London) citizens, the family drama seemingly depicts real provincial settings and representational country families. Two Angry Women takes place in the town of Abingdon which is south of Oxford University (where Henry Porter is purported to have graduated from), Merry Wives is set in the town of Windsor, the location of Windsor Castle which was used by Queen Elizabeth I as a place for royal court and diplomacy as well as entertainment, and Merry Devil is situated in the rural area of Edmonton north of London, known for its rumored supernaturality and land owned by the powerful Cecils in the late sixteenth century. The middle-class families in these plays were also, perhaps, meant to be accessible and realistic to common theatregoers. William Amos Abrams looks to R. B. Sharpe and the main

\footnotetext{
${ }^{3}$ Evett also calls attention to this viewpoint which was held by R. B. Sharpe: "Sharpe ... feels that the Abington plays came first in 1598, with The Merry Wives of Windsor closely following as a 'retort,' . . replied to by Porter's own Merry Women in 1599" (36).
} 
households in Merry Devil to suggest that the family drama may have been designed specifically to portray actual families either in existence at the time or in the past: "Professor Sharpe has advanced the opinion that the 'gentlemanly Clares, Jerninghams and Mounchenseys . . . appear to represent real country families,"” and "one can readily trace these family names in local records" (27). Abrams also speculates that the family drama was a versatile mode for playing companies because of the appeal to middle class tastes via the modification of names:

Such plays may possibly have grown out of a practice of adapting, by the use of family and local traditions of color, the strolling company's repertory of romances, comedies, and chronicles to such situations as would be constantly met on tour - a chance to perform in the guildhall of a town bursting with local pride, or in the great hall of a proud family. In the latter case the players may have found it more tactful, when there was the slightest tartness in the satire of moral dubiety in the plot, to assign names from the neighboring families, not from those present. (27-28)

Marianne Brish Evett in her critical edition of The Two Angry Women refers to Sharpe's attempt to categorize these similar plays under one umbrella term: "Sharpe places [The Merry Devil of Edmonton], as well as the Two Angry Women, in a category he calls 'Family Drama,' in which real families are portrayed, with detailed local references" (42). Although Abrams considers the Merry Devil to be a "topographical comedy," he too also refers to Sharpe in classifying it in similar terms, as he notes, "The Merry Devil of Edmonton establishes a type of drama called by [Professor Sharpe] 'Family Drama'" (27). Presumably, all three plays try to present real families, and by using topography that "would have been familiar to London audiences" (Bennett 61), the immersion theatregoers would have experienced while in attendance was likely made to appear even more life-like.

These three family drama plays, while each unique in their own right and therefore different from one another in a variety of ways, in general, follow the same plot structure and share the common themes of love and marriage like most early modern comedies. The family 
drama play typically features "a middle class country setting ... part of the action [taking] place in the dark," two families at odds with each other, "characters whose speech is full of proverbs," and parents "seeking to keep [their] daughter from marrying her true love" (Evett 34-35). Two Angry Women and Merry Wives "each featured adult, married women as protagonists; each was set in a small town; and in each the activities of the married women upstaged the attempts of young lovers to make it to the altar" (Howard 73), while the Merry Devil likewise features a small town setting, feuding families, and a young couple eloping in the middle of a confusing night scene against the wishes of their parents only to succeed in a final scene of reconciliation.

Referring specifically to Two Angry Women and Merry Wives, Jean E. Howard echoes Gurr when she states, "what is interesting is that two rival companies each staged plays in close temporal proximity that represent the role of adult women in small town life and build comedies around those women" (74), but these comedic family drama plays chiefly construct their plots around a contested middle-class love story. The young lovers in search of a matrimonial solution ends up becoming the focal point of these three plays. Indeed, if anything, the family drama's terminal culmination is a youthful marriage succeeding against social pressures and being imposed on the community to which both lovers are bound. Corresponding to its predecessors, the Merry Devil also depicts two young sweethearts fleeing their families in order to cement their marriage, an aspect of New Comedy which was "concerned with the maneuvering of a young man toward a young woman, and marriage [as] the tonic chord on which it ends" (Frye 59). This theme of individual choice, or lack thereof, in marital matters, especially the freedom for a daughter to choose her mate, is a deeply rooted cultural conflict, one that makes an appearance in many romantic comedy plays during the late Elizabethan period. The family drama play arguably not only "articulates and represents cultural change" on the stage, it "also participates in it; seeks 
not only to define, but actively generate, and in some cases to contain, cultural conflict" (Rose 1). In the introduction to The Expense of Spirit: Love and Sexuality in English Renaissance Drama, Mary Beth Rose states that "the Elizabethan and Jacobean periods witnessed major transformations in the social constructions of gender, conceptualization of the position of women, and the ideology of family" (2), all of which are unmistakably crucial components of the microcosms portrayed in Two Angry Women, Merry Wives, and Merry Devil.

Indeed, "controversial issues were dramatized in the plays of the period" (2), and the principal and overarching issue of daughterly agency within the system of marriage in these three family drama plays is actively rendered to look progressive due to a reconciliatory denouement. All three plays conclude with the successful marriage of two defiant juveniles who think they are in love coupled with a return to familial and communal harmony, activating the traditional conventions of comedy and at the same time giving the semblance of a liberal cultural shift in attitudes and expressions surrounding love and marriage. While the representation of parental resistance and challenging cultural and social conventions through the vehicle of an autonomous daughter figure is important, the societal mechanisms and especially the controlled system in which the daughter figure operates is still inherently conservative when it comes to matters concerning households, progeny, assets, and capital. Furthermore, although the comedically designed plots of Two Angry Women, Merry Wives, and Merry Devil zero in on the emergence of a transgressive middle-class daughter at last in wedlock, the reality is that the ways in which her love and companionate marriage are formed tend to originate from patriarchal and authoritative sources. That being said, the family drama's daughter figure does display varying levels of agency across the board. If the range of dates scholars have ascribed to the Two Angry Women, Merry Wives, and Merry Devil are in fact accurate, then we are able to see a pattern of 
progression within these family drama plays in regard to the agency exhibited by the daughter figure from pliable assent to unreserved repudiation of forced marriage.

\section{The Inculcation of Love and the Idea of Marriage in The Two Angry Women of Abingdon}

Relations between the two main households in Two Angry Women, the Barnes and Gourseys, are immediately hindered in Scene I after Mistress Barnes subtly accuses Mistress Goursey of flirting with her husband Master Barnes, who thanks her for coming to visit him in their place of residence: “And Mistress Goursey, I am much in debt / Unto your kindness, that would visit $m e$ " (1.30-31; emphasis added). Hearing this, Mistress Goursey rather foxily tells Master Barnes,

O, Master barnes, you put me but in mind Of that which I should say. 'Tis we that are Indebted to your kindness for this cheer; Which debt that we may repay, I pray let's have Sometimes your company at our homely house. (1.32-36)

to which Mistress Barnes sarcastically retorts, “That, Mistress Goursey, you shall surely have. / He'll be a bold guest, I warrant ye, / And bolder, too, with you than I would have him" (1.37-39). Without delay, Mistress Barnes interprets Mistress Goursey’s sense of gratitude as a sexual advance on her husband and continues with a string of sardonic rejoinders that belittle Master Barnes. Master Barnes, picking up on this uneasy hostility in the comfort of their home, says as an aside, "God's Lord, what / means the woman?" (1.52-53). The two couples move to play a game of tables in the orchard, but animosity between Mistress Barnes and Mistress Goursey persists and worsens. The end of Scene I sees Mistress Barnes exit with bitter contempt for Mistress Goursey, "Shall I shake hands? Let her go shake / her heels. / She gets nor hands nor 
friendship at my hands" (1.194-96), ${ }^{4}$ and Mistress Goursey apologize for the gibing between the wives:

I am sorry that it was our hap today

To have our pleasures parted with this fray.

I am sorry, too, for all that is amiss;

Especially that you are moved in this.

But be not so-'tis but a woman's jar. (1.205-09)

It is from this quarrel or "woman's jar" between the two angry women that a plan is devised to repair the wives' and subsequently their families' relationship.

Instead of Mall Barnes, the daughter figure, seeking out true love on her own accord, the idea of marriage is planted in her mind by her father and later by her brother Phillip Barnes. In Scene III, Master Barnes reflects on how to alleviate his wife's rage and realizes that his daughter may in fact be a tactical solution in plain sight:

Then I will study for a remedy. I have a daughter-now heaven invocate She be not of like spirit as her mother; If so, she'll be a plague unto her husband If that he be not patient and discreet, For that I hold the ease of all such troubleWell, well-I would my daughter had a husband, For I would see how she would demean herself In that estate- it may be ill enough And, so God shall help me, well-remembered now, Frank Goursey is his father's son and heir, A youth that in my heart I have good hope on. My senses say a match, my soul applauds The motion. O, but his lands are great: He will look high. Why, I strain myself To make her dowry equal with his land. Good faith, and 'twere a match, 'twould be a means To make their mothers friends. I'll call my daughter To see how she's disposed to marriage. (3.82-100)

Master Barnes conceives of a plan to try to convince his daughter Mall to marry Master Goursey's son Frank in the hope of restoring harmony between the two families. In an almost

\footnotetext{
4 Evett notes that "shake her heels" is a synonym for dance, but it also means "let her go hang" (104).
} 
impulsive power move on the part of her father, Mall is essentially commodified as a bargaining chip both to make the Barnes and Goursey mothers friends again and to match Mall with a suitable husband to ensure "She be not of like spirit as her mother," that is, angry and spiteful. 5 Master Barnes views Frank as "a youth that in my heart I have good hope on," for reasons not entirely known. Whatever the case may be, Master Barnes considers Frank an appropriate and timely match as a suitor for Mall, and without much more reason, the scheme to embed the idea of marriage in Mall's mind is initiated. In response to Master Barnes' hints ("I say 'tis good to marry" (3.108) and "But tell me, wench, hast thou a mind to marry?" (3.120), Mall gives a lengthy monologue on the reasons why she does not favor marriage, but eventually acquiesces to her father's authority:

... love swore me

To do what e'er my mother did before me.

Yet, in good faith, I have been very loath,

But now it lies in you to save my oath.

If I shall have a husband, get him quickly. (3.159-63)

Master Barnes' mere mentioning of marriage sets into motion Mall's destiny to be paired with a mate and eventually marry, a social convention she acknowledges she must adhere to.

Interestingly, by becoming a wife and leaving the Barnes household, Mall believes she will come to wield some degree of power, yet she fails to recognize that the male individuals involved in arranging her marriage, as well as her eventual husband, are the sources that maintain her power, not her:

... methinks I should

Wife it as fine as any woman could.

I could carry a port to be obeyed,

Carrying a mastering eye upon my maid,

With 'Minion, do your business, or I'll make ye;

\footnotetext{
5 "Wives, as we have seen, were enjoined to be obedient and to avoid contention. It was advice often repeated as when one Sussex gentlewoman was counselled to 'endeavour to please' her husband and to 'dwell with him in an amiable meekness of minde and doe not greeve his spirit with the least frowardness"' (Wrightson 69).
} 
And to all house authority betake me. (3.172-77)

Granted, though Mall would theoretically be in charge of a large portion of household matters as a wife, it is the facade of a higher degree of agency that helps convince Mall to seriously consider love and marriage. Keith Wrightson comments that "the naming of a wife as executor and the granting to her of full control of the family patrimony and the responsibilities of maintaining and bringing up under-age children, was not merely frequent in the wills of the period, it was normal" (68), which makes Mall's inclination to transition from the role of daughter to wife understandable. Wrightson also adds, "if there was a norm at most social levels, then it was perhaps that of complementary activity in day-to-day affairs" (68), and since the function of wife would bestow Mall more power and responsibilities within a newly developed household, her genuine desire to be married is both logical and strategic. Following Master Barnes' exit and Mall's mother Mistress Barnes' entrance towards the end of Scene III, this notion that marriage will lead to more agency is fortified in Mall by her mother's firm resistance to Mall marrying. Mistress Barnes's anger, which was originally directed at Mistress Goursey, carries over to reprimand her daughter into delaying marriage, as she tells Mall that she is "too young to marry" (3.191) and "Do ye hear, daughter, you shall stay my leisure!" (3.201). Mistress Barnes as a senex or blocking figure in stark contrast to her husband's encouraging wish for Mall to marry inadvertently strengthens Mall's desire to seek out a mate. Mall tells her mother, "I tell ye, mother, I say true; / Therefore, come husband, maidenhead adieu" (3.209-10), making one of the "angry women" even more irate as well as pushing along the plot to drive Mall towards "individual release" (Frye 61), the "green world" (Frye 67), and eventually marriage back in a harmonious normal or real world.

The Barnes son Phillip is close friends with the Goursey son Frank, and Phillip discloses to Master Barnes that the two share a kind of friendly love for each other. Master Barnes reacts 
positively to this piece of information and states, "Thou'st made my love complete unto thy

friend. / Phillip, I love him; and I love him so, / I could afford him a good wife I know" (3.29698), amplifying his inclination to match Mall to Frank. In a brisk back-and-forth between father and son, Mall's arranged marriage is settled for her without her knowledge or consent:

PHILLIP. Father, a wife?

MASTER BARNES. Aye, in good faith.

PHILLIP. Then, father, he shall have her! He shall, I swear.

MASTER BARNES. How canst thou say so, knowing not his mind?

PHILLIP. All's one for that. I will go to him straight.

Father, if you would seek this seven years' day

You would not find a fitter match for her.

And he shall have her, I swear he shall.

He were as good be hanged as once deny her.

I'faith, I'll to him. (3.299-308)

The invigorated father-son tag team also decide to bring Master Goursey on board, and with all of the male figures of the two families now stacked against the two angry women, Master Barnes confirms, "Phillip, if this would prove a match / It were the only means that could be found / To make thy mother friends with Mistress Goursey" (3.320-22). The Barnes' will also benefit from this uniting marriage in financial ways as Phillip notes, "Frank Goursey, he is rich; / His dowry, too, will be sufficient" (3.324-25), making the arranged match a favorable one in that it will help slightly to elevate their family's social station. Lastly, Phillip encapsulates, albeit quite bawdily, how the Barnes men will profit from Mall's marriage: “my sister's maidenhead / Stands like a game at tennis: if the ball / Hit into the hole or hazard, fare well all" (3.327-29).

Master Barnes has his virtually nonsensical servant, Nicholas Proverbs, deliver a letter with the marriage proposition to Master Goursey, and Phillip also follows in order to help convince Frank to agree. Frank is uneasy at first, and a little young for marriage (e.g. "not me, that am too young to marry" [6.15]), but eventually accepts their proposal even though he expresses absolutely no desire for marriage nor an attraction to Mall up to this point in the play. 
The two sons swiftly return to the Barnes residence before the day's end and Phillip sets Frank up outside of Mall's bedroom window so that he may attempt to woo her. Phillip informs his sister that "[Frank] is a gentleman of a good house," and "he's well-descended," and because of these attributes, "This gentleman, by all your friends' consent, / Must be your husband" (8.79, 81, 84-85). Even Frank chimes in to declare, "Why, take your first man, wench, and go no further" (8.112) to persuade Mall. After much discussion between the two, Mall accepts Frank's proposal and announces how her soon-to-be husband's social status is propitious for her (as well as her father): "Nor high nor low, but of the middle stature. / A middleman-that's the best size indeed. / I like him well; Love grant us well to speed" (8.120-22). Shortly before leaving for Oxford to marry the next day against the wishes of the two angry mothers, Mistress Barnes unexpectedly interrupts to discover Frank and Mall's plan to elope. Staying true to the title of the play, she is livid about their intentions and literally lays claim to ownership of her daughter in an attempt to obstruct the newly formed couple, as she exclaims, "Give me my daughter. Will ye rob me of her?" and "This wretch unnatural and undutiful, / Seeks hence to steal my daughter" (8.221, 225-26). This does not, however, prevent Mall and Frank from marrying in the final scene of the play.

Though Mall ultimately rejects her mother's demands, believes herself to have fallen in love, and as a result covets a marriage to Frank Goursey, all three of these decisions in actuality, though successfully executed by Mall, do not originate from her desires. The chief architects in resolving the two angry women's ongoing feud are Master Barnes and Phillip Barnes, and by arranging the unification of the two households through the management of Mall, she is unsuspectingly stripped of her own agency. Mall is treated as and rendered into a commodity; her body is manipulated to induce a stalemate between the wives through a constrained marriage. 
She is subservient to the subtle demands of her male family members, diminishing her to an easily controllable state of powerlessness. Given that "marriage among the property-owning classes in sixteenth-century England was . . . a collective decision of family and kin, not an individual one ... property and power were the predominant issues which governed negotiations for marriage" (Rose 16), ${ }^{6}$ Mall's propriety is evident in her resolution to impulsively carry out the arranged marriage to Frank.

\section{Peripheral Daughterly Agency in The Merry Wives of Windsor}

In what was possibly a reaction to the Admiral's Men's The Two Angry Women of Abingdon, the Lord Chamberlain's Men's The Merry Wives of Windsor retaliates by superficially restoring autonomy to the daughter figure, albeit in a far more reduced role. Though the main plot is unquestionably geared towards the cooperative antics of Windsor natives Mistress Ford and Mistress Page (contrasting the hatred Mistress Barnes and Mistress Goursey exhibit towards each other) in response to the outrageous outsider Sir John Falstaff, the mere presence of the eligible middle-class daughter figure in Anne Page gives the play its subtle family drama undercurrent. A Shakespeare comedy that is often praised for its celebration of women, Merry Wives certainly depicts moral, chaste, and good-spirited wives in Mistress Ford and Mistress Page, yet Anne Page, inasmuch as we would like to attribute the same characteristics to her, fails to become anything but another tractable household commodity that is exchanged in the controlled system of marriage.

Unlike Mall who is witty, humorous, and loquacious, Anne tends to be on the quieter side. Her tranquil and laconic nature is perhaps a result of curtailed agency, for when we

\footnotetext{
${ }^{6}$ Rose quotes from Lawrence Stone's The Family, Sex and Marriage in England 1500-1800
} 
compare Anne to the boisterous Mall, she is mitigated simply to the fine-featured "darling of Windsor" (Howard 76), a daughter who accepts her function in the family and is less obstinately rebellious about it. Remarkably, Anne only speaks nineteen times throughout the entirety of the play. By contrast, variants of her name (Anne Page, Anne, Nan, etc.) surface in small-town conversations close to three times the rate as Anne's speaking parts. We in fact learn much more about Anne through channels of town gossip and her three suitors Slender, Doctor Caius, and Master Fenton than from Anne herself.

The "darling of Windsor" is the hot topic around town and we are able to formulate her character through instances of indirect communication. Anne is a proper chaste maiden from an upper middle-class family, hence the high number of suitors that seek her hand in marriage. At the very beginning of the play, Welshman Sir Hugh Evans states, "There Anne Page, / which is daughter to Master George Page, which is pretty / virginity," to which Slender adds, "Mistress Anne Page? She has brown hair and speaks / small like a woman" (1.1.39-43). Although she is under eighteen years of age, her pronounced ladylike features and femininity make her a desirable candidate for a wife. Messenger and attendant to the querulous French Doctor Caius, Mistress Quickly, adds to the belief that Anne is a kind, well-rounded young woman, as she states, "Anne is a good girl" (1.4.30) and refers to her as "good / Anne Page" (2.1.47-48). Most notably, we learn that Anne comes with a considerable dowry, an attribute arguably more attractive than her good looks. In the opening of the play, Evans discloses this to Slender and his nephew:

It is that fery person for all the 'orld, as just as you will desire, and seven hundred pounds of moneys, and gold and silver, is her grandsire upon his death's bed-Got deliver to a joyful resurrections - give, when she is able to overtake seventeen years old. It were a goot motion, if we leave our pribbles and prabbles, and desire a marriage between Mas- 
ter Abraham [Slender] and Mistress Anne Page. (1.1.44-50)

The wealth of "seven hundred pounds of moneys, and gold and / silver" that is linked with marrying into Anne's family is no doubt a strong motive for suitors to pursue her. The financial factor in the form of a substantial dowry is mirrored in Frank Goursey in Two Angry Women, one of the main reasons why Frank becomes an ideal match for Mall and the Barnes men. Even Master Fenton, Anne's final choice in a mate, credits the financial prospects he sees in Anne as the starting point for falling in love with her.

In a surprising moment of candidness during their first meeting in the play, Fenton reveals that Master Page does not favor him because of his higher social status and "wild" past:

He doth object I am too great of birth And that, my state being galled with my expense, I seek to heal it only by his wealth.

Besides these, other bars he lays before meMy riots past, my wild societiesAnd tells me "tis a thing impossible I should love thee but as a property. (3.4.4-10)

Page believes that Fenton aims to marry Anne in order to access her dowry money which would consequently pay off old debts. In a roundabout way through Fenton's speech, Page confirms how suitors, as well as fathers, in the family drama regard the daughter figure; that they are to primarily be loved "but as a property." Fenton admits this to Anne a few lines later:

Albeit I will confess thy father's wealth Was the first motive that I wooed thee, Anne, Yet wooing thee, I found thee of more value Than stamps in gold or sums in sealèd bags, And 'tis the very riches of thyself

That now I aim at. (3.4.13-18)

Though he initially began his pursuit of Anne because of her "father's wealth," Fenton realizes that she is "of more value" than the grand family wealth she comes with. This apparently honest revelation is enough to cement the young couple's commitment to each other, and Anne holds 
Fenton to re-request permission to marry her from her father, as she states, "Gentle Master Fenton, / Yet seek my father's love, still seek it, sir" (3.4.19-20). Though on the surface Anne demonstrates a degree of agency in selecting her husband-to-be, she automatically recognizes how her new lover must appeal to her father, the authority figure legally in charge of her body, for final approval.

After committing herself to Fenton at the end of Act III Scene iv, Slender steps in to make his final claim only to divulge that he too finds love secondary to her dowry, and that the driving forces behind his search for a mate are the male counterparts of both families: "Truly, for mine own part, I would little or nothing / with you. Your father and my uncle hath made motions" (3.4.59-60). Page enters to press Anne to accept Slender's proposal and to do away with the idea of marrying Fenton, as he states overbearingly, "Now, Master Slender. — Love him, daughter Anne," and "I told you, [Fenton], my daughter is disposed of" $(3.4 .64,67)$. This assertive, possessive language reinforces the notion that Anne is considered a marriage commodity, one that is protected and exchanged cautiously in order to ensure that the best interests of the family are sustained. Once again, though Page directs his daughter to "love" Slender, the actual practice of love is treated as subsidiary to the social rank, financial value, and reputation of the suitor and his family. Page regards Fenton as "too great of birth," but also recoils at his past behavior as a profligate and libertine, leading Page to shield Anne for his own protection.

In a departure from total parental disapproval in the Two Angry Women, Anne's mother eventually supports her daughter though she cannot bring herself to approve of Fenton as Anne's future husband. When Anne begs her mother not to be paired with the dull Slender, Mistress Page reassures her, "I mean it not. I seek you a better husband" (3.4.81) but manifests the same 
authority as Master Page in wanting to govern their daughter's marriage. This was of course customary at the time as "individual, rather than parental choice of a spouse, let alone prior affection between potential mates" was thought to be "foolish, undesirable" (Rose 16). At the same time, "the marital hopes of daughters could . . . be effectively thwarted by failure to gain parental approval for their matches," but the individualism Anne retaliates with endorses the view that "some young women could show considerable independence in their matchmaking" (Wrightson 53).

We are to believe that Fenton and Anne's bond is transformed into the play's only real romantic love, that in the face of stern parental opposition over economic and progenitorial concerns, true love prevails over all. Amidst the backdrop pranks Mistress Page and Mistress Ford play on Falstaff, the stubborn Ford wearing away because of his belief that his wife is wanton, and Mistress Quickly pretending to help potential suitors woo Anne Page, Anne, of her own accord, certainly does select the best suitor she encounters in spite of her parents' preferences (Master Page/Slender, Mistress Page/Doctor Caius). However, the convention that Anne must dutifully submit to what is essentially an arranged marriage is both known and understood by her beforehand, and Anne's decision to elope with the objectionable Fenton develops within the controlled power structures of domestic Windsor. More specifically, it is progenial security that dictates the daughter's match with an appropriate mate. Therefore, Anne's volition in picking Fenton over the other preselected suitors merely gives the impression that Anne conducts her own marital affairs, when in reality her agency is being carefully regulated by her family.

\section{Supernatural Aid and Communal Rallying in The Merry Devil of Edmonton}


The Merry Devil of Edmonton postdates the Two Angry Women and Merry Wives by a few years as it was "evidently written towards the end of the reign of Queen Elizabeth I" (Bennett xi). The second half of the play's "nocturnal scenes reflect a vogue for such scenes between about 1597 and 1603 [for example, A Midsummer Night's Dream ... and Henry Porter's Two Angry Women of Abingdon]" (Bennett xi), aligning the Merry Devil with other contemporaneous plays in the family drama genre around the turn of the century. For the most part, the play adheres to the typical localized setting, romantic comedy structure, and wily plot devices synonymous with family drama, but deviates by introducing an occult element. The play's opening induction distinctly separates it from the Two Angry Women and Merry Wives; Cambridge scholar and magician Peter Fabell, who has sold his soul to the devil, entraps and coerces the spirit Coreb to extend his time on the earthly plane by seven years. Fabell claims, "I have earnest business for a private friend," and demands, "let me rise and, ere I leave the world, / Dispatch some business that I have to do" (Induction 35, 38-39). Fabell is then released to the community of Edmonton with the undefined task of helping his friends in some way.

Fabell's objective is to facilitate the union of young lovers Millicent Clare and Raymond Mounchensey, to bring them and their conflicted families together for the purpose of marriage in a cheerful conclusion. After the Clare family arrives at the George Inn in Act I Scene i, Sir Arthur Clare and his wife Dorcas seek to upgrade their daughter Millicent's upcoming marriage in the garden, a devious act of plotting which harkens back to Master Barnes' machinations involving Mall in his family garden. With Millicent eavesdropping on her parents, we learn a few key facts about her relationship with her betrothed, Raymond, in passing, as Clare discloses, “Two tedious winters have past o'er since first / This couple lov'd each other and in passion / Glued first their naked hands with youthful moisture-" (1.1.51-53). Compared to Mall who was 
subliminally induced into marriage and Anne who merely picked the best candidate out of a group of set suitors, Millicent is an agent of her own love relationship. Her affaire de coeur with Raymond is one of "passion" and at least two years old, a timespan absent in romances in the Two Angry Women and Merry Wives. Furthermore, nothing in the text indicates that the two lovers were arranged by their parents formally to meet in the past with the purpose of marriage in mind. Therefore, Millicent and Raymond's love for each other may arguably be considered more genuine than the relationships previously discussed.

Financial matters in the Merry Devil are again responsible for interfering with the daughter's planned marriage. Clare explains to his wife Dorcas how "crosses of love still thwart this marriage" (1.1.64) because of Sir Richard Mounchensey's recent series of unfortunate events:

For look you, wife, the riotous old knight Hath overrun his annual revenue In keeping jolly Christmas all the year: The nostrils of his chimney are still stuff'd With smoke more chargeable than cane-tobacco; His hawks devour his fattest dogs, whilst simple, His leanest curs eat his hounds' carrion; Besides, I heard of late his youngest brother, A Turkey merchant, hath sure suck'd the knight By means of some great losses on the sea, That, you conceive me, before God, all's naught. His seat is weak: thus each thing rightly scann'd, You'll see a flight, wife, shortly of his land. (1.1.68-80)

The Mounchenseys becomes a less than ideal match for the Clares due to ongoing financial burdens, making Raymond too risky of a venture. Wealth, or lack thereof, is tied to the issue of progeny, which is to say that Clare's anxiety around whom his only daughter will marry is of great importance because it will ultimately determine the continuation of his family's capital, property, and power ("She is the last is left me to bestow" [2.2.29]). The Jerningham son, Frank, who happens to be a friend of Raymond's, is instead considered due to the greater extent of his 
family's wealth. The magician Peter Fabell echoes this notion in Act I Scene ii in a monologue addressing Mounchensey:

And after all these promises, by Clare?

Refuse to give his daughter to thy son

Only because thy revenues cannot reach

To make her dowage of so rich a jointure

As can the heir of wealthy Jerningham? (1.2.61-64)

Differing from the active and outspoken wives in the Two Angry Women and Merry Wives,

Dorcas is submissive, agrees wholeheartedly with her husband's decision making, and serves no larger function in the rest of the play. Without any questioning, she goes along with Clare's plan to commit Millicent to Chestnut Nunnery so that he can orchestrate a more suitable marriage to "the lusty heir / Of Sir Ralph Jerningham" (1.1.102-103), the young Frank. At the end of Act I Scene i, Dorcas states rather openly to Clare, "Your care argues the love you bear our child; / I will subscribe to anything you'll have me" (1.1.105-106), reinforcing her willingness to do anything for her husband. Yet behind the scenes, Millicent has learned exactly what her father intends to do with her and consequently takes action to make sure she and Raymond end up together.

Clare's final decision to commit Millicent to Chestnut Nunnery for one year is to prevent his daughter's marriage to Raymond whilst organizing a more appropriate match with the wealthier Jerninghams and their son Frank. ${ }^{7}$ Millicent's unavailability as a wife, in theory, would also deter the Mounchensey family altogether, leading them to pursue other avenues in the marriage exchange system to find Raymond a wife who is suitable to their social station while being in accordance with their assets. Clare, however, does not foresee nor prepare for a coordinated resistance against his plan. Surprisingly, Clare's new favorable choice for

\footnotetext{
${ }^{7}$ Interestingly, Rose notes, "Sensing that the men are not quite ready for grown-up reality, which in Elizabethan comedy means married love, the women, true to romance tradition, demand one year of separation complete with appointed tasks for their lovers before marriage can take place" (36).
} 
companion to Millicent, Frank Jerningham, opposes the marriage outright and decides to work together with Raymond and his magician friend Peter Fabell to reunite and consummate their long-term love relationship. Still, even with admirable intentions, Fabell, Frank, and Raymond play into the highly controlled male-dominated structure of marital exchange. Fabell states, "we are the men must ply this match" $(2.2 .85)$, reiterating how marriage is still supervised by commandeering men. Even in the most liberal of all three family drama plays in regards to daughterly agency, it would seem as though power-wielding heads of households as well as authoritative men are determinants of the daughter figure's final choice in a mate in the Merry Devil.

As Millicent and Raymond's stratagem to elope from Chestnut nunnery to Enfield Chase is initiated, Millicent's brother Harry joins the group and even more members of the Edmonton community turn to help the young couple succeed. The end of Act III Scene ii marks the involvement of the forest keeper Brian in aiding Millicent decamp (aided by Frank and Harry) to Enfield and later the George Inn at Waltham to meet Raymond:

RAYMOND. To Brian's upper lodge in Enfield Chase; $\mathrm{He}$ is mine honest friend and a tall keeper. I'll send my man unto him presently T'acquaint him with your coming and intent.

FABELL. Be brief and secret.

RAYMOND. Soon at night remember You bring your horses to the willow ground.

FRANK. 'Tis done; no more. HARRY. We will not fail the hour.

RAYMOND. My life and fortune now lies in your power. (3.2.162-69)

Running through the "zona torrida of the" Enfield "forest" (4.1.2) at night, Frank, Harry, and Millicent are briefly split up when they hide from Edmonton natives Sir John, Banks, Blague, and Smug who are deer hunting, but eventually rendezvous with Brian and receive his altruistic 
help. ${ }^{8}$ With the fathers Clare and Jerningham in close pursuit behind them, Brian steps in to distract the men so that the adolescents can escape:

MILLICENT. Alas, what shall we do?

BRIAN. If you go to the lodge you are surely taken;

Strike down the wood to Enfield presently, And if Mounchensey [Raymond] come I'll send him t'ye.

Let me alone to bustle with your father. I warrant you that I will keep them play

Till you have quit the Chase. Away, away! (4.2.98-104)

The host of the George, Blague, also assists Millicent and Raymond by marrying them the following morning at his own place. The last scene of the play sees Clare and Jerningham awaken believing they are at the George Inn. Blague enters because he has discovered that the sign to his inn has been switched with the inn opposite, courtesy of Smug the smith via Fabell, which further flusters Clare and Jerningham who are still under the impression that they have spent the night at the George. Blague then reveals to the two fathers that there was "a marriage that's in my house this morning" (4.2.161), which commences the familial and community reconciliation typical of romantic comedy endings.

With tremendous help from her brother, the new suitor turned-ally Frank, Peter Fabell, and many other Edmonton natives, Millicent is able to defy and bypass her father. From having her original marriage to Raymond cancelled and supplanted by a new union with Frank to being committed to Chestnut nunnery, Millicent is dealt with and moved as a pawn, but in the end breaks away from her father's grasp. Instead of Raymond pleading his case to his love's father, like Fenton does in Merry Wives, Millicent completes her transgression by confronting Clare on her own. Raymond states, "Sir Arthur Clare, my new created father, I beseech / you, hear me"

\footnotetext{
${ }^{8}$ Millicent's mother's name "Dorcus" is apparently a translation of the Greek name "Tabitha," which is Aramaic for "gazelle."
} 
(4.2.206-7), but never speaks again. It is largely Millicent as well as Fabell the supernatural peacemaker who contribute to the final formation of a reconciled and cohesive community.

\section{"Rise, daughter": Closing Remarks}

The family drama's daughter figure outwardly appears to perform the duties of an exemplary unmarried early modern woman; she is obedient to some degree and willing to go through marriage as directed by her father. Wrightson maintains that this was of the utmost significance for a woman in the process of shifting to the role of wife as he states, "the qualities conventionally ascribed to a good wife were essentially submissive," and "wives ... were enjoined to be obedient and to avoid contention" $(65,69)$. Though the daughter may emerge from the fray following elopement in the dark as an autonomous, blossomed, and transgressive victor, she exhibits varying levels of agency and possesses different desires. Mall's marriage is covertly orchestrated behind closed doors and then willfully completed. The suggestible Anne elects to join forces with Fenton only after being wooed by him but also due to the lackluster state of the other suitors. Millicent is resolute in preserving her long-term love relationship with subsequent interventions from a supernatural aid and members of her rural community. In the genre of family drama, the emergent agential daughter epitomized by Mall, Anne, and Millicent all drive towards a matrimonial resolution, but do so gradually in terms of individuality when dealing with love and marriage.

At the core of the central love interests in these plays, a kind of liberalization of the daughter figure as well as marriage itself materializes. The agency Millicent displays in marrying out of love and being devoted to her long-term partner of choice Raymond fills the gaps left by 
Mall and Anne. She also very likely follows certain procedures outlined by Wrightson that gave her an advantage over her daughterly counterparts:

it is clear that in the courtships of . . . daughters, the initiative usually belonged to the young couple. Suitors presented themselves and sought his approval to woo formally, while once matters were under way the girls themselves were allowed the final and absolute say over the completion of the match. The implication is that the girl concerned had already given the young man sufficient encouragement to make his formal approach but that matters would not proceed further without parental approval. (53)

Moreover, during the early modern period, "parental power over the choice of marriage partners remained absolute, but a right of veto was conceded to the young parties to a match," and eventually "this situation persisted until the later seventeenth and eighteenth centuries, when a double shift took place," whereupon "greater autonomy was allowed to wives" (Wrightson 48). Within the arc of the love relationships that we see in the Two Angry Women, Merry Wives, and Merry Devil, the first daughter we are introduced to opens with a nonexistent sense of selfdetermination. Mall Barnes is clever and well-spoken, but the romance and marriage she ultimately comes to embrace feels inorganic because her brother's and father's subterfuge influence and dictate her course of action. Mall unknowingly delivers a completion to a veiled arranged marriage, and this is both expected of her and anticipated by the scheming male characters in the play (Master Barnes, Phillip Barnes, and Frank Goursey). Anne Page is aware that an arranged marriage is in the making for her ("This is my father's choice" [3.4.33]), but unlike Mall, she participates in the premarital games of courtship ("What is your will?" and "I mean, Master Slender, what would you with / me?" [3.4.57, 61-2]). She is stern and inflexible to certain suitors such as Slender and expresses this disapproval to her mother while acquiescing to Fenton's advances. To some extent, Anne recognizes her position in the Page family as an exchangeable bridal object and she actively assumes the function of a marriageable daughter. It is through this compliance that Anne obtains some degree of limited power in determining her 
choice of mate in marriage. Millicent is the only daughter out of the three to have a prior love relationship in the beginning of the play that is approved. The Millicent-Raymond romance is both sanctioned by both family parties and advanced to a proposed marriage. Though Millicent's parents make last-minute arrangements without her consent to change out Raymond for a wealthier suitor of higher social status (Frank), this proposition is rejected by Millicent and nearly everyone else in the Edmonton community. Following Millicent's rebellion in which she takes charge of her own affairs and intent to marry Raymond, her replacement fiancée Frank, Raymond, her brother Harry, the magician Peter Fabell, as well as many other Edmonton natives, collectively mobilize to secure Millicent's exertion of agency. In contrast to Mall's and Anne's experiences, Millicent is successful in her liberation from parental authority, and her magnanimous helper Peter Fabell aptly summarizes her achievement of self-determination when he declares, "No law can curb the lovers' rash attempt: / Years in resisting this are sadly spent. / Smile then upon your daughter and kind son" (5.1.265-67).

Rose asserts that "the drama not only illuminates the inner life of the surrounding culture but plays a significant part in creating it" (11), but more importantly the Two Angry Women, Merry Wives, and Merry Devil and their respective dramatists produced plays that incorporated critical contemporary cultural issues concerning love and marriage while competing with each other, which in turn perhaps helped engender social shifts. With each play responding to and informing its counterparts, some of the normative discourses within the plays themselves are indirectly addressed, accentuated, and brought to the forefront of the conversation regarding daughterly agency. Comparable daughter figures of course exist outside of the family drama in other early modern dramatic genres, and later Elizabethan and Jacobean plays set in similar domestic settings perhaps indicate a progression in daughterly autonomy and reduced maternal 
power. Plays close in proximity such as Thomas Dekker's The Shoemaker's Holiday (1599) sees royal and therefore divine intervention in the character of the King who sides with the two lovers Rose Oatley and Rowland Lacy. In the final scene of the play, the King first nullifies their unsanctioned marriage only to remarry them shortly after:

Dost thou not know that love respects no blood, Cares not for difference of birth or state? The maid is young, well born, fair, virtuous, A worthy bride for any gentleman. (5.5.99-102)

Rose also notes the triumph of individuality in Shakespeare's A Midsummer Night's Dream (1599), albeit with minor caveats:

The dramatic conflict of $A$ Midsummer Night's Dream is, of course, set in motion by the issue of individual choice of a mate versus forced marriage. Although the young lovers triumph over irrational parental opposition to their desires, their victory is suffused with irony. The lovers imagine that they are defiantly asserting their individuality; but the lack of differentiation among them and the mix-up in the forest clarify both their lack of uniqueness and the arbitrary quality of their choices. (38)

Similarly, the much later Jacobean play 'Tis Pity She's a Whore by John Ford features a seemingly benevolent father, Florio, voicing his opinion that his daughter Annabella has the ability to choose her future husband: "I will not force my daughter 'gainst her will," and "I would not have her marry wealth, but love" $(1.3 .3,11)$. Even Shakespeare's late play The Tempest (1610-11) presents us with the moderately compliant Miranda break away from her father Prospero as she falls in love at first sight with Ferdinand and proceeds to marry him, though this is also the intended result of Prospero's behind-the-scenes sorcery and therefore a manifestation of paternal power. In reference specifically to late Elizabethan comedies, Rose states, "although the playwrights discerned the outlines of comic structure in the drama of sexual desire seeking and finding satisfaction, they represented potentially conflicting social and erotic forces mainly in order to reconcile them" (42). However impractical or unrealistic or 
"uncomfortable an audience may be with the resolution of a comic play, that discomfort centers on an imagination of the future" (Rose 8), and the progressively changing portrayal of the family drama's daughter figure perhaps aims to address this vision. In the end, the prefiguration of a progressive early modern middle-class daughter as well as a recreated harmonious community that is ready to accept her is the end result of playwrights and their play companies competing, informing, and inadvertently shaping each others' dramaturgical output and spheres of influence. 


\section{Works Cited}

Abrams, William Amos. The Merry Devil of Edmonton, 1608. Duke University Press, 1942.

Howard, Jean E. 'Sharp-tongued women and small-town social relations in Porter's Two Angry Women of Abington and Shakespeare's The Merry Wives of Windsor." The Merry Wives Of Windsor New Critical Essays, edited by Evelyn Gajowski and Phyllis Rackin, Abingdon, Routledge, 2014, pp. 73-83.

Frye, Northrop. “The Argument of Comedy." English Institute Essays, edited by D. A. Robertson Jr., AMS Press, 1965, pp. 58-73.

Gurr, Andrew. "Intertextuality at Windsor. (Sources of William Shakespeare's Plays)." Shakespeare Quarterly, vol. 38, no. 2, 1987, pp. 189.

Gurr, Andrew. "Intertextuality in Henslowe: A Reply.” Shakespeare Quarterly, vol. 39, no. 3, 1988, pp. 394-398.

Porter, Henry. Henry Porter's The Two Angry Women of Abington: A Critical Edition. Ed. Marianne Brish Evett. New York, Garland, 1980.

Rose, Mary Beth. The Expense of Spirit: Love and Sexuality in English Renaissance Drama. Cornell University Press, 1988.

Shakespeare, William. The Merry Devil of Edmonton. Ed. Nicola Bennett. Globe Education and Theatre Arts Books/Routledge, 2000.

Shakespeare, William. The Merry Wives of Windsor. The Norton Shakespeare: Comedies. 3rd ed. Ed. Stephen Greenblatt, et al. New York, W.W. Norton \& Company, 2016.

Wrightson, Keith. English Society, 1580-1680. Rutgers University Press, 1982. 